\title{
Assessment of bacterial loads of Clarias gariepinus (Burchell, 1822) obtained from cultured and natural habitats
}

\author{
Olajide Joseph Afolabi*, Oluwole Olakunle Oladele and Fayokemi Christianah Olususi
}

\begin{abstract}
Background: African catfish (Clarias garipienus) is a major tropical aquaculture species in Africa and most cultivated by fish farmers in Nigeria. The dominance of African catfish for fish farming is attributed to several favourable characteristics such as its ability to tolerate a varying range of environmental conditions, high stocking densities under culture conditions, fast growth rate, acceptability of artificial feed, high fecundity rate, ease of artificial breeding and high market value. However, catfishes are known to harbour bacteria which limit its suitability for human consumption. Hence, this study was conducted to compare the bacterial loads of C. gariepinus from cultured and natural habitats.

Methodology: A total number of twelve live adult (200-799 g) C. gariepinus comprising 3 each were randomly obtained from two cultured habitats (ponds) and two natural habitats (rivers). In the laboratory, the skin and the intestine of the fish were examined for the presence of bacteria using nutrient, mannitol salt and cetrimide agars.

Results: Seven bacteria isolates namely, Pseudomonas aeruginosa, Bacillus subtilis, Staphylococcus aureus, Staphylococcus epidermis, Micrococcus luteus, Escherichia coli and Streptococcus spp. were identified from the catfishes using their colonial, morphological and biochemical characteristics. The results showed that the total bacterial loads in cultured habitat (skin, $25.77 \times 10^{4} \mathrm{cfu} / \mathrm{g}$; intestine, $22.50 \times 10^{4} \mathrm{cfu} / \mathrm{g}$ ) were significantly higher than the total bacterial load recorded in natural habitat (skin, $15.94 \times 10^{4} \mathrm{cfu} / \mathrm{g}$, intestine, $14.23 \times 10^{4} \mathrm{cfu} / \mathrm{g}$ ). Specifically, total Staphylococcal loads (skin, $10.40 \times 10^{4} \mathrm{cfu} / \mathrm{g}$; intestine, $10.77 \times 10^{4} \mathrm{cfu} / \mathrm{g}$ ) and Pseudomonad loads (skin, $6.80 \times$ $10^{4} \mathrm{cfu} / \mathrm{g}$; intestine, $8.00 \times 10^{4} \mathrm{cfu} / \mathrm{g}$ ) were significantly higher in cultured habitat than natural habitat where Staphylococcal loads (skin, $6.66 \times 10^{4} \mathrm{cfu} / \mathrm{g}$; intestine, $5.50 \times 10^{4} \mathrm{cfu} / \mathrm{g}$ ) and Pseudomonad loads (skin, $5.46 \times 10^{4} \mathrm{cfu}$ / $\mathrm{g}$; intestine, $5.54 \times 10^{4} \mathrm{cfu} / \mathrm{g}$ ) were recorded. Generally, it was observed that bacterial loads were higher on the skin compare to intestines of $C$. gariepinus obtained from both habitats.
\end{abstract}

Conclusion: The study showed that bacterial loads were more in C. gariepinus obtained from cultured habitat compared to those obtained from natural habitat. It is therefore recommended that sanitary conditions under which fish are reared in fish pond should be improved.

Keywords: Bacteria loads, Clarias gariepinus, Isolates, Ponds, Rivers

* Correspondence: ojafolabi@futa.edu.ng

Department of Biology, Federal University of Technology Akure, Akure,

Nigeria

(c) The Author(s). 2020 Open Access This article is licensed under a Creative Commons Attribution 4.0 International License, which permits use, sharing, adaptation, distribution and reproduction in any medium or format, as long as you give appropriate credit to the original author(s) and the source, provide a link to the Creative Commons licence, and indicate if changes were made. The images or other third party material in this article are included in the article's Creative Commons licence, unless indicated otherwise in a credit line to the material. If material is not included in the article's Creative Commons licence and your intended use is not permitted by statutory regulation or exceeds the permitted use, you will need to obtain permission directly from the copyright holder. To view a copy of this licence, visit http://creativecommons.org/licenses/by/4.0/. 


\section{Background}

Fish is one of the affordable sources of quality protein that is available worldwide for human consumption (Olugbojo \& Ayoola, 2015). It is one of the main food components of humans for many centuries and still constitutes an important part of the diet of many countries (Eze, Echezona, \& Uzodinma, 2011). Fishes are consumed for their high biological values in terms of high protein retention in the body, low level of cholesterol and presence of essential amino acids. Fish is also an important source of income for fishermen and fish farmers and its cultivation is a source of employment in developing countries (Felix, Robert, Christopher, Christian, \& Christiana, 2018)

The African catfish (Clarias gariepinus) has been reported to be a very important freshwater fish in Nigeria and aquaculture industries (Federal Department of Fisheries, 2007) due to its several favourable characteristics such as its ability to tolerate a varying range of environmental conditions, fast growth rate, high fecundity rate, ease of artificial breeding and it commands good price (Eyo, Ekanem, \& Jimmy, 2014). Its consumption is on the increase in both rural and urban centres in Nigeria due to its highly nutritive values (Federal Department of Fisheries, 2007; Emikpe, Adebisi, \& Adedeji, 2011). However, consumption of fish can be of risk of bacterial contamination due to their aquatic habitat which is easily polluted by wastes from homes, farmlands, industries and the use of animal manure as pond fertilizer in fish farming. These contaminants can render such fish unfit for human consumption (Danba et al., 2015) as they take in large number of bacteria into their alimentary tract from food and water sediment which are capable of causing pathogenic diseases (Adedeji, Tiamiyu, \& Emikpe, 2011).

Bacteria found on fish majorly belong to genera of Pseudomonas, Staphylococcus, Flavobacterium, Vibrio, Micrococcus, Bacillus and Aeromonas, some exist as microflora in pond water and large water bodies and they can be found on the gills, skin, fin or in the intestinal tracts of fish under normal conditions but due to environmental stress they may produce epizootics diseases while some are also pathogenic organisms (Oladosu-Ajayi, George, Obasa, Ajayi, \& Bankole, 2011). The pathogenic bacteria associated with fish as classified by Kvenberg (1991) and Rodricks (1991) are indigenous and non-indigenous bacteria; the non-indigenous bacteria contaminate the fish or their habitat one way or the other and examples include Escherichia coli, Clostridium botulinum, Shigella dysenteriae, Staphylococcus aureus, Listeria monocytogens and Salmonella, while the indigenous bacteria pathogens are found living naturally in the fish's habitat for example, Vibrio species and Aeromonas species (Rodricks, 1991) which are not harmful to fish but may be harmful to man on consumption (Salihu et al., 2012). Thus, the aim of this study was to assess and compare the bacterial loads of C. gariepinus obtained from cultured and natural habitats in Ondo state. The findings of this research will add to knowledge on the types of bacteria associated with freshly collected samples of C. gariepinus from the selected habitats and it will be useful in managing aquaculture farms.

\section{Materials and methods Study sites}

The study sites for this research were two fish ponds where C. gariepinus are cultured namely, Ayodele fish pond (pond A) (latitude $7^{\circ} 17^{\prime} 50^{\prime \prime} \mathrm{N}$, longitude $5^{\circ} 9^{\prime} 0^{\prime \prime} \mathrm{E}$ ) and Abbey fish pond (pond B) (latitude $7^{\circ} 16^{\prime} 59^{\prime \prime} \mathrm{N}$, longitude $5^{\circ} 9^{\prime} 32^{\prime \prime} \mathrm{E}$ ). Both were located within Akure, a major city in Ondo State in South-western, Nigeria, located within latitudes $7^{\circ} 07^{\prime} \mathrm{N}$ to $7^{\circ} 37^{\prime} \mathrm{N}$ and between longitudes $5^{\circ} 06^{\prime} \mathrm{E}$ and $5^{\circ} 38^{\prime} \mathrm{E}$. The two natural habitats used (for natural C. gariepinus) were as follows: Owena reservoir (river A) (between latitude $7^{\circ} 15^{\prime} \mathrm{N}$, longitude $5^{\circ} 5^{\prime} \mathrm{E}$ and latitude $7^{\circ} 4{ }^{\prime} \mathrm{N}$, longitude $4^{\circ} 47^{\prime} \mathrm{E}$ ) which was situated across Owena River located in the suburb of Owena town in Ifedore Local Government Area of Ondo-State and Igbokoda River (river B) (latitude $6^{\circ} 21^{\prime}$ $\mathrm{N}$ and longitude $4^{\circ} 48^{\prime} \mathrm{E}$ ) situated in Igbokoda town is in Ilaje-Ese Odo, Ondo State.

\section{Ethics and consent}

The ethic and consent concerning the use of fish for this research were deemed unnecessary according to the Federal Institute of Industrial Research. Meanwhile, the number of fishes used for this research was regulated by the institute.

\section{Sample collection and preparation}

A total number of twelve (12) live adult African catfish (C. gariepinus) of different weight range (200-799 g) were purchased randomly from the mentioned locations comprising of three (3) C. gariepinus samples from each of the locations. The fishes were transported live in a clean plastic keg containing water to Biology Research Laboratory, of the Federal University of Technology, Akure for further examinations. In the laboratory, the fishes were identified as C. gariepinus using external features described by Idodo-Umeh (2003).

\section{Bacteriological analysis}

The catfishes were dissected using sterile dissecting kits and bacterial isolates were subsequently obtained from the skin and intestine of the catfishes. General purpose medium (nutrient agar) and selective media (mannitol salt and cetrimide agars for the enumeration of Staphylococcus and Pseudomonas respectively) obtained 
commercially in powdered form were prepared according to the manufacturer's instruction and the media solution were sterilised by autoclaving at $121{ }^{\circ} \mathrm{C}$ for 15 min.

One (1) gram of skin and intestine of the fish samples was weighed separately and macerated aseptically. The fish tissues (skin and intestine) were put into two separate test tubes containing $9 \mathrm{ml}$ of sterile distilled water to give $10^{-1}$ dilution and shaken thoroughly. The stock solutions were serially diluted up to $10^{-3}$ as described by Willey, Sherwood, and Woolverton (2008).

Plating (pour plate method) was done by pipetting 1 $\mathrm{ml}$ of the $10^{-3}$ each at the centre of three different sterile Petri dishes by using sterile syringes. Cooled but molten agar media were poured into the Petri dishes containing the inoculums and swirled to evenly distribute the agar and organisms. After the solidification of the media, the plates were inverted and incubated at $27{ }^{\circ} \mathrm{C}$ for $24 \mathrm{~h}$. The plates were examined after incubation and the number of colony forming units (CFU) that developed were counted and recorded.

Further sub-culturing of the representative colonies were carried out on a freshly prepared nutrient agar, mannitol salt agar and cetrimide agar media to obtain pure culture of microorganisms. These were further incubated at $37{ }^{\circ} \mathrm{C}$ for $24 \mathrm{~h}$ in order to obtain pure cultures. All of the above procedures were carried out under aseptic environment to avoid contamination of cultured organisms.

\section{Characterisation/identification of isolates}

The characterisations of the bacterial isolates were based on colonial, morphological and biochemical characteristics of colonies. Macroscopic examination of surface colonies on the agar media was used to determine the colour, edge, elevation, surface and shape of microorganisms (Abu, Monica, \& Uwadirioha, 2016). Morphological characteristics were studied on the oil immersed slide under the microscope after using Gram staining technique described by Christian Gram in 1884 (Willey et al., 2008). Biochemical tests such as catalase test, starch hydrolysis test and sugar fermentation test using maltose, sucrose, glucose, lactose and galactose sugars were also carried out on the bacteria isolates according to methods described by Olutiola, Famurewa, and Sonntag (2000), Ogbulie, Ogbulie, and Njoku (2001), Fawole and Oso (2004) and Willey et al. (2008).

\section{Data analysis}

The bacterial loads of the skin and intestines of the fish samples from cultured and natural were subjected to one-way analysis of variance (ANOVA) at $p<0.05$ and significant differences were observed. The means were separated using Duncan multiple range test.

\section{Results}

Total bacterial, Staphylococcal and Pseudomonad loads of C. gariepinus from cultured and natural habitats

The total bacterial, Staphylococcal and Pseudomonad loads found on the skin and intestine of C. gariepinus obtained from cultured and natural habitats were presented in Table 1. The result showed that, the mean values of bacterial loads ranged between $8.67 \times 10^{4}$ and $13.5 \times 10^{4}$ $\mathrm{cfu} / \mathrm{g}$ for skin, while the range for intestine was between $6.83 \times 10^{4}$ and $12.20 \times 10^{4} \mathrm{cfu} / \mathrm{g}$. It was further observed that the bacterial loads on the skin of C. gariepinus obtained from river A were significantly different $(p<0.05)$ from those obtained from pond A and pond B. This observation was the same with the bacteria loads of intestine of examined C. gariepinus samples from cultured habitat when compared with natural habitat. Generally, it was observed that bacterial loads were higher on the skin compare to intestines of C. gariepinus.

Furthermore, the mean value of Staphylococcal loads on skin and intestines of C. gariepinus ranged from $3.13 \pm$ $0.50 \times 10^{4}$ to $6.03 \pm 1.67 \times 10^{4} \mathrm{cfu} / \mathrm{g}$ and $2.40 \pm 0.40 \times 10^{4}$ to $6.00 \pm 1.22 \times 10^{4} \mathrm{cfu} / \mathrm{g}$ respectively. For the skin, there was no significant difference $(p>0.05)$ between Staphylococcal loads on C. gariepinus obtained from pond A, pond $\mathrm{B}$ and river A. However, there was significant difference $(p$ $<0.05$ ) between C. gariepinus obtained from pond A and river B. Furthermore, Staphylococcal load was higher on the skin compare to intestines of C. gariepinus obtained from both cultured and natural habitats under observation except for pond A which recorded slightly higher Staphylococcal loads of $4.77 \pm 0.55 \times 10^{4} \mathrm{cfu} / \mathrm{g}$ in intestines compared to the skin $\left(4.37 \pm 0.72 \times 10^{4} \mathrm{cfu} / \mathrm{g}\right)$.

In addition, the mean values of Pseudomonad loads as presented in Table 1 ranged from $2.63 \pm 0.60 \times 10^{4}$ to $4.17 \pm 0.51 \times 10^{4} \mathrm{cfu} / \mathrm{g}$ on the skin and $2.47 \pm 0.55 \times 10^{4}$ to $4.20 \pm 0.20 \times 10^{4} \mathrm{cfu} / \mathrm{g}$ in the intestines. The Pseudomonad loads recorded from the skin of $C$. gariepinus obtained from pond A $\left(13.5 \pm 3.10 \times 10^{4} \mathrm{cfu} / \mathrm{g}\right)$ were significantly higher than pond B $\left(12.27 \pm 2.47 \times 10^{4} \mathrm{cfu} /\right.$ g). Meanwhile, the Pseudomonad load from the skin of catfishes obtained from river A $\left(2.40 \pm 0.40^{\mathrm{a}} \times 10^{4} \mathrm{cfu} / \mathrm{g}\right)$ and river $\mathrm{B}\left(2.63 \pm 0.44^{\mathrm{a}} \times 10^{4} \mathrm{cfu} / \mathrm{g}\right)$ were not significantly different from each other $(p>0.05)$. Generally, it was noted that the highest Pseudomonad loads $(4.20 \times$ $10^{4} \mathrm{cfu} / \mathrm{g}$ ) were obtained in the intestines of C. gariepinus cultured in pond A, while the least Pseudomonad loads $\left(2.47 \times 10^{4} \mathrm{cfu} / \mathrm{g}\right)$ were obtained in the intestine of C. gariepinus obtained from River A (Table 1).

\section{Colonial, morphological and biochemical characteristics of various bacterial isolated from cultured and natural habitats}

Seven (7) bacteria isolates were obtained from C. gariepinus in both cultured and natural habitats (Table 2). 
Table 1 Total bacterial, Staphylococcal and Pseudomonad loads of C. gariepinus from cultured and natural habitats

\begin{tabular}{|c|c|c|c|c|c|c|c|c|}
\hline \multirow[b]{2}{*}{ Habitats } & \multirow[b]{2}{*}{ Locations } & \multirow[b]{2}{*}{ No. of fish examined } & \multicolumn{2}{|c|}{$\begin{array}{l}\text { Total bacterial loads (CFU/g } \times \\
10^{4} \text { ) }\end{array}$} & \multicolumn{2}{|c|}{$\begin{array}{l}\text { Staphylococcal loads (CFU/g } \times \\
\left.10^{4}\right)\end{array}$} & \multicolumn{2}{|c|}{$\begin{array}{l}\text { Pseudomonad loads (CFU/g } \times \\
10^{4} \text { ) }\end{array}$} \\
\hline & & & Skin & Intestine & Skin & Intestine & Skin & Intestine \\
\hline \multirow[t]{2}{*}{ Cultured } & Pond A & 3 & $13.5 \pm 3.10^{c}$ & $12.20 \pm 3.12^{c}$ & $6.03 \pm 1.67^{b}$ & $6.00 \pm 1.22^{b}$ & $4.17 \pm 0.51^{b}$ & $4.20 \pm 0.20^{c}$ \\
\hline & Pond B & 3 & $12.27 \pm 2.47^{\mathrm{bc}}$ & $10.30 \pm 0.27^{b c}$ & $4.37 \pm 0.72^{\mathrm{ab}}$ & $4.77 \pm 0.55^{b}$ & $2.63 \pm 0.67^{a}$ & $3.80 \pm 0.20^{b c}$ \\
\hline Total & & 6 & 25.77 & 22.50 & 10.40 & 10.77 & 6.80 & 8.00 \\
\hline \multirow[t]{2}{*}{ Natural } & River A & 3 & $7.27 \pm 1.10^{\mathrm{a}}$ & $6.83 \pm 0.55^{\mathrm{a}}$ & $3.13 \pm 0.50^{\mathrm{ab}}$ & $2.40 \pm 0.40^{\mathrm{a}}$ & $2.83 \pm 0.60^{a}$ & $2.47 \pm 0.55^{\mathrm{ab}}$ \\
\hline & River B & 3 & $8.67 \pm 0.70^{a b}$ & $7.40 \pm 0.92^{\mathrm{ab}}$ & $3.53 \pm 0.83^{\mathrm{a}}$ & $3.10 \pm 0.44^{\mathrm{a}}$ & $2.63 \pm 0.60^{a}$ & $3.07 \pm 0.81^{a}$ \\
\hline Total & & 6 & 15.94 & 14.23 & 6.66 & 5.50 & 5.46 & 5.54 \\
\hline
\end{tabular}

These isolates include 2 Gram negative rods bacteria (Escherichia coli and Pseudomonas aeruginosa), 1 Gram positive rod bacterium (Bacillus subtilis) and 4 Gram positive coccal bacteria (Staphylococcus aureus, Staphylococcus epidermis, Micrococcus luteus and Streptococcus spp.). The result presented in Table 2 showed their edge, colour, elevation, shape and various identification tests by which these bacteria species were identified. The identification tests showed that all bacteria isolates were found to hydrolysed starch except $E$. coli, S. epidermis and Streptococcus spp. The S. aureus and $S$. epidermis isolated were found to be catalase positive, fermented sucrose, lactose, maltose and galactose but $S$. epidermis was found to be coagulase negative and also ferment glucose while $S$. aureus did not ferment glucose. The result also revealed that Streptococcus spp. exhibited positive reaction to coagulase test but negative to catalase test, fermented glucose, lactose and maltose but did not ferment sucrose and galactose.

Bacillus subtilis and Micrococcus luteus isolated were found to be positive to coagulase test and also ferment glucose, sucrose and galactose but did not ferment maltose. However, Bacillus subtilis was found to react positively to catalase test and also ferment lactose, whereas Micrococcus spp. did not ferment lactose and reacted negatively to catalase test. Moreover, Pseudomonas aeruginosa was found to ferment only glucose sugar, negative to coagulase test but positive to catalase test.

\section{Occurrence of bacteria isolates from C. gariepinus obtained from cultured and natural habitats}

The occurrence of bacteria species isolated from C. gariepinus from both habitats was presented in Table 3. It was observed that $S$. aureus, $P$. aeruginosa and S. epidermis were obtained in $C$. gariepinus sampled from both cultured and natural habitats. E. coli was present in $C$. gariepinus obtained from river A and river B which are both natural habitats, while Micrococcus luteus was isolated from all $C$. gariepinus sampled except those obtained from river B of the natural habitat. However, Streptococcus spp. and B. subtilis were only present in pond A of the cultured habitat.
Mean \pm SD with the same superscript along column is not significantly different $(p>0.05)$ using Duncan multiple range test

\section{Discussion}

\section{Total bacterial loads of C. gariepinus from cultured and natural habitats}

The bacteria isolated from this study were similar to the works of Olugbojo and Ayoola (2015) who compare bacteria loads in fish species of commercial importance at the aquaculture unit and lagoon front of the University of Lagos, also Tivkaa and Sampson (2013) and Osungbemiro, Sanni, and R., O. Olaniyan, R. F., and Olajuyigbe, A. O. (2014) in Ibadan Southwest and Ondo State respectively. From the study so far, it could be deduced that the higher loads of these bacteria are from cultured habitat when compared to natural habitat, this may be attributed to restriction in the movement of water in which C. gariepinus is being reared, and this water restriction encourages the growth of bacteria. Also, the use of organic fertilizers for pond fertilization such as poultry manure and uneaten feed waste which when broken down can serve as substrate for bacteria. This assertion is supported by Ajani, Orisasona, and Omitoyin (2016) and Albert, Felix, Solomon, and Emeh (2016). Ajani et al. (2016) suggested that the application of poultry manure in fish ponds despite its numerous advantages should be consciously regulated such that public health will not be compromised.

\section{Bacterial loads on skin and intestines of examined $C$. gariepinus}

The highly infected part of the examined C. gariepinus used for bacteriological studies was the skin compared to the intestine, this may be due to the fact that the skin is always in contact with the surrounding water and also, the skin may get contaminated with bacteria during handling. This observation agrees with the work of Shinkafi and Ukwaja (2010) who recorded high bacterial loads on the skin of fresh Tilapia fish (Oreochromis niloticus) when compared with the intestines and gills; Adebayo Tayo, Odu, Igwiloh, and Okonko (2012) also made 


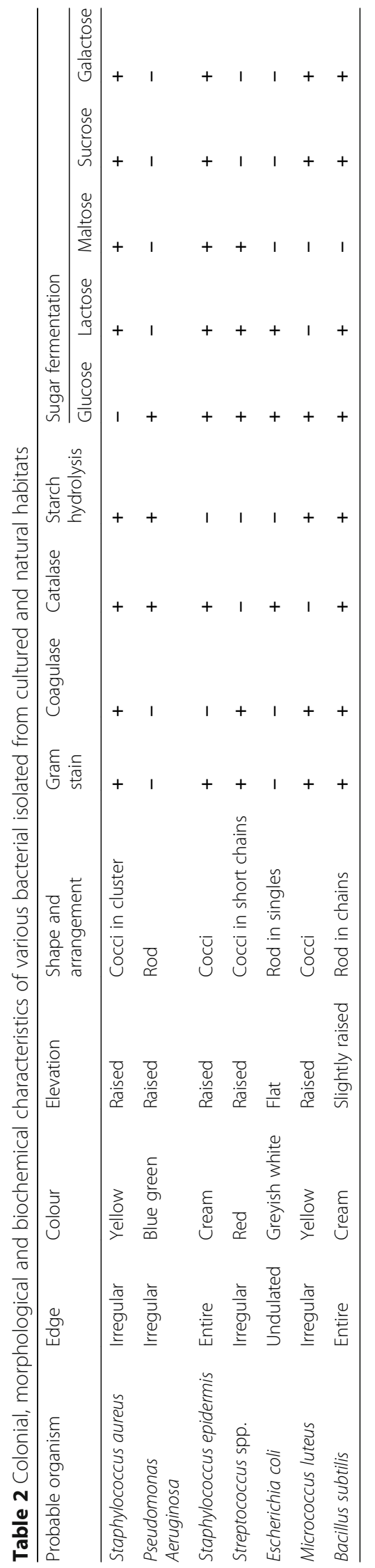


Table 3 Occurrence of bacteria isolates from C. gariepinus obtained from cultured and natural habitats

\begin{tabular}{|c|c|c|c|c|}
\hline \multirow[t]{2}{*}{ Bacterial isolates } & \multicolumn{2}{|c|}{ Cultured C. gariepinus } & \multicolumn{2}{|c|}{ Natural C. gariepinus } \\
\hline & Pond $\mathrm{A}$ & Pond $B$ & River A & River B \\
\hline S. aureus & + & + & + & + \\
\hline P. aeruginosa & + & + & + & + \\
\hline S. epidermis & + & + & + & + \\
\hline Streptococcus spp. & + & - & - & - \\
\hline E. coli & - & - & + & + \\
\hline Micrococcus luteus & + & + & + & - \\
\hline B. subtilis & + & - & - & - \\
\hline
\end{tabular}

$+=$ present,$-=$ absent

similar observation but this observation was in contrary to the work of Olugbojo and Ayoola (2015) who reported high population of bacteria in the gut of three fish species sampled in Lagos State when compared with gills and skin; likewise Ajani et al. (2016) and Albert et al. (2016), also reported high bacterial loads in the intestine.

\section{Occurrence of bacteria isolates from C. gariepinus obtained from the studied habitats}

The occurrence of Staphylococcous spp. observed from the two habitats is an indication of contamination of $C$. gariepinus by man during fish harvesting and handling process; this observation agrees with the work of Eze et al. (2011). The isolation of enteric organisms such as $E$. coli is particularly useful as an indicator of faecal contamination (Carla \& Maria, 2016) and from this study, $E$. coli was found to occur in river $\mathrm{A}$ and river $\mathrm{B}$ which are both natural habitat and they are both large unprotected river. Therefore, the presence of E. coli may be due to the presence of faecal pollution caused by human and other environmental wastes in the water bodies from which the C. gariepinus was obtained, similar observation was also made by Osungbemiro et al. (2014).

The result of bacteria population of $10^{4} \mathrm{cfu} / \mathrm{g}$ conforms to the finding of Osungbemiro et al. (2014), who reported lower counts of $10^{4} \mathrm{cfu} / \mathrm{g}$ for C. gariepinus in fresh and brackish water habitats of Ondo State. Tivkaa and Sampson (2013) reported $1.2 \times 10^{4}-2.16 \times 10^{4} \mathrm{cfu} / \mathrm{g}$ and also with the report of Abu et al. (2016). However, lower bacterial population was reported by Adedeji et al. (2011). The authors reported bacterial counts in the range of $10^{12}-10^{13} \mathrm{cfu} / \mathrm{g}$ in Ibadan. Egbere, Akadiri, Oyero, Odewumi, and Zakari (2010) also reported bacterial counts in the range of $10^{6}-10^{8} \mathrm{cfu} / \mathrm{g}$ in their study of catfish ponds in Jos, metropolis, Northern Nigeria. The $10^{4} \mathrm{cfu} / \mathrm{g}$ bacterial loads of the bacteria species obtained from the two habitats in this study were less than $10^{6} \mathrm{cfu} / \mathrm{g}$; according to Eze et al. (2011), any fish that have more than $10^{6}$ bacteria count in one gram is not suitable for human consumption.

However, the presence of bacteria from this study, although still within acceptable range poses threat to consumer health that depends on freshwater fish for source of protein. Fish and fish products have been reported by Novotny, Dvorska, Lorencova, Beran, and Pavlik (2004), Hastein et al. (2006) and Efuntoye, Olurin, and Jegede (2012) to be vehicles of food-borne bacterial infections in humans. Enterotoxins produced by $S$. aureus are of public health importance because the toxins are serious cause of gastroenteritis after consumption of fish and related products (Salihu et al., 2012), P. aeruginosa could cause general inflammation and sepsis in critical body organs such as lungs, urinary tract, which can be fatal because it thrives in moist surfaces and $E$. coli have been implicated for a number of gastroenteric diseases such as diarrhoea, dysentery and vomiting as reported by Udeze et al. (2012), while Bacillus spp. are implicated in causing a wide range of infectious diseases including abscesses, food borne infections, ear infections, respiratory and urinary infections (Morales et al., 2004) and also some of these isolates are potential spoilage organisms of unprocessed fish.

\section{Conlusion}

This study has revealed the presence of bacteria in the two habitats under study. High population of bacteria was recorded more on the skin compared to the intestine. Also, bacterial loads were higher in cultured habitat when compared to natural habitat which is as a result of restriction in the movement of water and decomposition of uneaten feed waste. The presence of pathogenic bacteria in this study is of public health importance as they can be transmitted to man. Based on this study, it is therefore recommended that, treatment of organic manure before introduction into ponds should be incorporated to reduce bacterial contamination of fish ponds; regular draining of pond after specific period of time should be encouraged in order to limit bacteria loads; intrusion of man into the wild habitat of the host fish through contamination of water with human faeces and domestic waste should be avoided and fish should be properly cooked before consumption so as to destroy bacteria harboured.

\section{Abbreviations}

FDF: Federal Department of Fisheries; FAO: Food \& Agriculture Organization

\section{Acknowledgements}

The authors acknowledge the assistance rendered by the management of Ayodele fish farm and Abbey fish farm as well as the fishermen at Owena and lgbokoda Rivers in providing fish samples used for this study. We also acknowledge Mr. A.O. Akinduroti who served as our guide to Igbokoda town during the fish collection. 


\section{Authors' contributions}

$\mathrm{OJA}$ and FCO were involved in fish collection from both ponds and rivers. The dissection of the catfishes was also done by OJA and FCO. Authors OJA, $\mathrm{OOO}$ and FCO participated in the study design and data analysis. OJA and FCO gathered the literatures for the manuscript. The first draft of the manuscript was prepared by FCO and edited by OJA and OOO. The final manuscript was read and approved by all the authors.

\section{Funding}

Not applicable

\section{Availability of data and materials}

All data generated or analysed during this study are included in this published article.

\section{Ethics approval and consent to participate}

Not applicable

\section{Consent for publication}

Not applicable

\section{Competing interests}

The authors declare that they have no competing interests.

\section{Received: 2 January 2020 Accepted: 26 May 2020}

Published online: 03 June 2020

\section{References}

Abu, O., Monica, G., \& Uwadirioha, U. (2016). Comparative study on bacterial load in intestine, gills and skin of cultured African catfish (Clarias Gariepinus) from different locations in Rivers state, Nigeria. International Journal of Innovative Studies in Aquatic Biology and Fisheries, 2(3), 21-29.

Adebayo Tayo, B. C., Odu, N. N., Igwiloh, N. J., \& Okonko, I. O. (2012). Microbiological and physicochemical level of fresh catfish from different markets in Akwa Ibom state, Nigeria. New York Science Journal, 5(4), 46-52.

Adedeji, O. B., Tiamiyu, A. M. \& Emikpe, B. O. (2011). Isolation and identification of aerobic bacterial flora of the skin and stomach of wild and cultured Clarias gariepinus and Oreochromis niloticus from Ibadan, Southwest Nigeria. Journal of Applied Sciences Research, 7(7), 1047-1051.

Ajani, E. K., Orisasona, O., \& Omitoyin, B. O. (2016). Comparision of bacterial flora and frequency of occurrence in water and Clarias gariepinus raised in ponds fertilized with raw poultry manure. Journal of Fisheries Sciences, 10(1), 016021.016

Albert, A. C., Felix, E. C., Solomon, O. E., \& Emeh, C. C. (2016). Effect of habitat locations on the bacteriological and physicochemical assessment of aquaculture freshwater catfish (Clarias gariepinus) using small scale depuration system. Journal of Advances in Microbiology, 1(1), 1-9.

Carla, R., \& Maria, A. C. (2016). Assessmenet of the microbiological quality of recreational waters: Indicators \& methods. Euro-Mediterranean Journal of Environmental Integration, 2, 25.

Danba, E. P., David, D. L., Wahedi, J. A., Buba, U., Bingari, M. S., Umaru, F. F., ... Thomas, T. L. (2015). Microbiological analysis of selected catfish ponds in Kano Metropolis, Nigeria. Journal of Agriculture and Veterinary Science, 8(8), 74-78.

Efuntoye, M. O., Olurin, K. B., \& Jegede, G. C. (2012). Bacterial flora from healthy Clarias gariepinus and their antimicrobial resistance pattern. Advance Journal of Food Science and Technology, 4(3), 121-125.

Egbere, O. J., Akadiri, S., Oyero, O., Odewumi, P., \& Zakari, H. (2010). Bacteriological quality of catfish ponds in Jos metropolis, Nigeria. International Journal of Bioscience, 5(2), 95-103.

Emikpe, B. O., Adebisi, T., \& Adedeji, O. B. (2011). Bacterial load on the skin and stomach of Clarias gariepinus and Oreochromis niloticus from Ibadan, Southwest Nigeria: Public health implications. Journal of Microbial Biotechology Research, 1(1), 52-59.

Eyo, V. O., Ekanem, A. P., \& Jimmy, U. I. (2014). A comparative study of the gonadosomatic index (GSI) and gonad gross morphology of African catfish (Clarias gariepinus) fed unical aqua feed and Coppens commercial feed. Croatian Journal of Fish, 72(2), 63-69.

Eze, E. I. Echezona, B. C \& \& Uzodinma, E. C. (2011). Isolation and identification of pathogenic bacteria associated with frozen mackerel fish (Scomber scombrus) in a humid tropical environment. African Journal of Agricultural Research, 6(7), 1918-1922.

Fawole, M. O., \& Oso, B. A. (2004). Characterization of Bacteria: Laboratory Manual of Microbiology, (4 $4^{\text {th }}$ edition, pp, 24-33). Ibadan, Nigeria: Spectrum Book limited.

Federal Department of Fisheries. (2007). Fisheries Statistics of Nigeria, $\left(4^{\text {th }}\right.$ Edition, p. 1995)

Felix, A. I., Robert, U. O., Christopher, C. E., Christian, U., \& Christiana, O. I. (2018). Economic of small holder fish farming to poverty alleviation in the Niger Delta region of Nigeria. Turkish Journal of Fisheries \& Aquatic Sciences., 19(4), 313-329.

Hastein, T. B., Hjeltnes, J., Lillehaug, U., Skare, M., Berntssen, H., \& Lundebye, A. K. (2006). Food safety hazards that occur during the production stage: Challenge for fish farming and the fishing industry. Review in Science and Technology, 25, 607-625.

Idodo-Umeh, G. (2003). Freshwater Fishes of Nigeria (Taxonomy, Ecological Notes, Diet and Utilization), (pp 119 - 129). Benin City - Nigeria: Idodo-Umeh Publishers Limited.

Kvenberg, E. J. (1991). Non-indigenous bacterial pathogen. In: Microbiology of Marine Food Products. Donn, R., Cameron, H., Van Nostrand, R. (Eds), New York, (pp. 263-291).

Morales, J., Moreno, J., Merino, S., Tomas, G., Martinez, J., \& Garmamszegi, L. S. (2004). Association between immune parameteas, parasitism and stress in breeding pied flly catcher blue tits (parus caeauleus) a medication field experiment. Annales Zoological Fennici, 42, 45, -56.

Novotny, L., Dvorska, L., Lorencova, A., Beran, V., \& Pavlik, I. (2004). Fish: A potential source of bacterial pathogens for human beings. Veterinary Research Institute, 9, 343-358.

Ogbulie, T. E., Ogbulie, J. N., \& Njoku, H. O. (2001). Comparative study on the microbiology and shelf life stability of palm wine from Elaeis guineensis and Raphia hookeri obtained from Okigwe, Nigeria. African Journal of Biotechnology, 6(7), 914-922.

Oladosu-Ajayi, R. N., George, F. O., Obasa, S. O., Ajayi, A. A., \& Bankole, M. O. (2011). Bacterial load, composition and succession in the African catfish, Clarias gariepinus (Burchell, 1822) held at ambient temperatures. Researcher, 3(7), 67-73.

Olugbojo, J. A., \& Ayoola, S. O. (2015). Comparative studies of bacteria load in fish species of commercial importance at the aquaculture unit and lagoon front of the University of Lagos. International Journal of Fisheries and Aquaculture, 7(4), 36-46.

Olutiola, P. O., Famurewa, O., \& Sonntag, H. G. (2000). Introduction to General Microbiology: A practical Approach. (2 ${ }^{\text {nd }}$ edition, pp.267) Bolabay publications, Ikeja.

Osungbemiro, N. R., Sanni, R. O., Olaniyan, R. F., \& Olajuyigbe, A. O. (2014). Bacteria flora in the gut and respiratory organs of Clarias gariepinus in fresh and brackish water habitats of Ondo state, Southwest Nigeria. World Academy of Science, Engineering and Technology International Journal of Animal and Veterinary Sciences, 8(6), 558-561.

Rodricks, E. G. (1991). Indigenous pathogen: Vibrionaceae of microbiology of marine food products. (pp. 285-295), Reinhold, New York.

Salihu, M. D., Junaidu, A. U., Magaji, A. A., Falekle, O. O., Yusuf, Y., Abubakar, M. B., ... Samaila, S. (2012). Bacteriological quality of freshwater fishes caught from Sokoto River, Sokoto, Nigeria. Journal of Veterinary Advances, 2(1), 65-69.

Tivkaa, J. A., \& Sampson, U. N. (2013). Bacterial flora of African catfish (Clarias gariepinus) harvested from ponds in Uyo south-South Nigeria. Journal of Environmental Science, Toxicology and Food Technology, 5(3), 72-76.

Udeze, A. O., Talatu, M., Ezediokpu, M. N., Nwanze, J. C., Onoh, C., \& Okonko, I. O. (2012). The effect of Klebsiella pneumoniae on catfish (Clarias gariepinus). Reseacher, 4(4), 51-59.

Willey, J. M., Sherwood, L. M., \& Woolverton, C. (2008). Prescott, Harley and Klein's microbiology, (pp. 264-273). New York: McGraw Hill Higher Education.

\section{Publisher's Note}

Springer Nature remains neutral with regard to jurisdictional claims in published maps and institutional affiliations. 